DOI https://doi.org/10.32837/app.v0i66.714

УДК 327:321.01:930.2(=511.111=113.6)

\author{
М. В. Яковлєb \\ orcid.org/0000-0001-7774-3513 \\ кандидат політичних наук, доцент, \\ завідувач каредри міжнародних відносин, \\ керівник Школи політичної аналітики \\ Національного університету «Києво-Могилянська академія»
}

\title{
МИНУЛЕ ЯК ВІДОБРАЖЕННЯ КОНЦЕПЦІЙ СУЧАСНОСТІ В МІЖНАРОДНИХ ВІДНОСИНАХ: ОБМЕЖЕННЯ ТА МОЖЛИВОСТІ ПРЕЗЕНТИЗМУ
}

Постановка проблеми. Історія є самостійною наукою, яка займається дослідженням подій минулого, але разом з тим результати історичних розвідок є цінним матеріалом для ідеологів та політиків. Можна припустити, що встановлення історичної істини, під якою розуміється достовірне з'ясування подій минулого («так, як насправді було»), встановлення фактів минувшини, дозволяє відкинути ідеологічні інсинуації. Разом з тим важко собі уявити такий ідеальний стан, за якого історія абсолютно перестає бути привабливою як базис, на якому ідеологи та політики конструюють свої надбудови.

Під час інтерпретації подій сучасності часто можна побачити намагання відстежити в цих подіях «вияви основних структурних змін чи глибоких історичних трендів» (Савельева, Полетаев, 2005, с. 67). Так само важко собі уявити, за яких обставин суспільство відмовиться від спокуси тлумачити те, що відбувається нині, порівнюючи це з тим, що відбувалося колись. Особливо це стосується міжнародних відносин: зв'язки між країнами традиційно розглядаються в їхній історичній динаміці, що імпліцитно передбачає реінтерпретацію всієї складної історії взаємовідносин держав одна з одною. Тому презентизм варто розглянути не лише як деструктивне явище «викривлення» минулого, але і як неминучий стан речей.

Аналіз публікацій. Безпосередньо феномену презентизму приділяють увагу у своїх дослідженнях історики та філософи (Савельева, Полетаев, 2005). Із протидії презентизму «виростали» цілі школи, наприклад Кембриджська школа інтелектуальної історії (Атнашев, Велижев, 2018), представники якої К. Скіннер і Дж. Покок дозволяли собі навіть витончено насміхатися над презентистськими працями своїх сучасників, які стосувалися інтелектуальної спадщини відомих мислителів (Скиннер, 2018 [1988], с. 82).

Можна знайти приклади глибоких історичних розвідок, у яких інтелектуальні напрацювання дослідників розглядаються в контексті історичних та соціальних процесів часів, за яких вони жили і творили. Прикладом цього може бути чудова праця англійської дослідниці ренесансної культури Ф.А. Сйтс, присвячена Джордано Бруно та його творчості, про що вона напише так: «В його ідеях та замислах тісно переплелися три лінії - герметизм, мнемоніка, луллізм» (Сйтс, 2018, с. 8), без розуміння яких в історичному контексті тогочасної Свропи важко зрозуміти і праці самого Джордано Бруно.

Існує велика кількість праць, у яких інтелектуальна спадщина мислителів минулого осмислюється в категоріях сучасності (Portis, 1998). Однак серед дослідників історії міжнародних відносин антипрезентистські підходи є відносно новими (Schmidt, 1994), оскільки міжнародні відносини та їхню історію здебільшого викладають так, наче «ії можна пояснити, покликаючись на сталу традицію, яка сягає своїм корінням давніх Афін і продовжується до сучасності» (Schmidt, 2013, с. 8). Отже, такий стан речей є інтелектуальним викликом сучасним дослідникам, які не можуть цілковито відмовитися від погляду на події минулого абсолютно абстраговано від подій сучасності, однак при цьому вони мають не приписувати діячам минулого поглядів, яких ті не могли дотримуватися.

Мета статті полягає у розкритті обмежень і окресленні можливостей презентизму як відображення в минулому концепцій сучасності на прикладі міжнародних відносин. 
Досягнення цієї мети передбачає виокремлення сутнісних характеристик презентизму, виділення основних стратегій, за яких презентистський підхід може бути конструктивним. Це ілюстрація його обмежень на прикладі конкретного матеріалу, яким у цій статті є праця, присвячена шведсько-фінським відносинам в історичній перспективі шведського історика Г. Ліндквіста.

Виклад основного матеріалу. Цікавим і дуже промовистим квазітерміном на позначення феномену презентизму під час інтерпретації подій сивої давними з позицій сучасності є термін «флінстонизація» (англ. flinstonization), який 1996 року у своїй книзі, присвяченій культурі США, запропонував американський дослідник Л. Левін (Levin, 1996). Термін конотує до відомого мультиплікаційного серіалу, в якому головними героями є родина Флінстоунів, які живуть в часи Кам'яного віку, але при цьому їхній побут пародійним чином нагадує сучасний стиль життя з автомобілями, офісною роботою, домашнім приладдям. Зрозуміло, що перші наші пращури не конструювали автомобілів і не саджали папугу в ящик для імітації телевізора - це здається нам кумедним.

Натомість комічний ефект не завжди помітний у тих випадках, коли ми, наприклад, читаємо, що, мовляв, Платон був мислителем тоталітарним, а праці якогось вченого негідні згадки через те, що його співпраця з якимось політичним режимом ніби-то дискредитувала його твори. Однак на цю проблему історіографи звернули увагу, про що російські дослідники І. Савельєва та А. Полєтаєв пишуть так: «Усвідомлення упередженості, політизованості історії стало характерною рисою історіографії Нового часу» (Савельева, Полетаев, 2005, с. 64). Варто зауважити, що це розуміння поширюється також і на розуміння історії міжнародних відносин.

Інтерпретація минувшини може набувати різних форм. Б. Шмідт, дослідник історії розвитку та становлення теорії міжнародних відносин як самостійної дисципліни, критикує презентизм саме через те, що через реінтерпретацію творів минулого видатні мислителі зараховуються до «таборів» конкретних теоретиків, про що вони, вочевидь, у свої часи могли навіть не здогадуватися.

Література з міжнародних відносин містить численні покликання на ідею про існування епічних традицій міжнародної думки (international thought), з яких постали цілі школи чи парадигми, такі як реалізм і лібералізм (Schmidt, 2013, с. 8). Чи міг знати Фукідід, що він опиниться в «клубі» теоретиків-реалістів? Презентистський підхід, як слушно зауважує Б. Шмідт, перешкоджає дослідженню процесів історичного розвитку теорій міжнародних відносин як самостійної дисципліни, оскільки він «помиляється в тому, що плутає аналітичну традицію 3 історичною, внаслідок чого виникають численні перешкоди у відстеженні справжнього історичного розвитку міжнародних відносин (Schmidt, 2013, с. 9).

Звісно, автору цього речення можна дорікнути за вживання словосполучення «справжній розвиток», однак його критика заслуговує на увагу: як можна дізнатися, чим саме мотивувалися мислителі минулого, коли писали свої твори, якщо ми постфактум вписуємо їх у свої ідеологічні та методологічні рамки та «нарікаємо» їх представниками наших сучасних інтелектуальних шкіл?

Особливо потужним антидотом проти презентизму є Кембриджська школа інтелектуальної історії, методологічний підхід якої відомий також під назвою контекстуалізм, а іноді навіть як «новий історицизм», як полюбляють його називати критики Кембриджської школи (King, 1995). Засновники й основні представники цієї школи К. Скіннер і Дж. Покок справді робили особливий наголос на тому, що для розуміння текстів конкретних авторів необхідно обов'язково враховувати широкий спектр обставин появи цього тексту, тобто контекст, та особливості політичної мови (Thorup, 2019), якою цей твір був написаний, які тогочасні дискусії відображені у тексті, з ким саме дебатує автор.

К. Скіннер відомий своїм класичним питанням, у якому втілена і теорія іллокутивних актів Дж. Остіна: «Що саме робив автор своїм висловлюванням?» (Атнашев, Велижев, 2018, с. 26). Ключ до протидії презентизму полягає в суті питання: не те, що ми робимо нині, коли інтерпретуємо той чи інший текст, а що саме за допомогою тексту як сукупності висловлювань робив автор свого часу, коли писав свій текст.

Безумовно, реінтерпретація подій і текстів минулого не є виключно негативним явищем i такі практики не завжди є тим негативним презентизмом, який викривлює наше розуміння минулого. Вважаю, що конструктивними можуть бути дві стратегії: 1) свідоме та відкрите 
опрацювання творів минулого в рамках чітко заданої сучасної методології з тим, щоб не приписувати авторам минулого того, що вони не могли навіть уявити, а для відстеження історичного розвою складних концептів; 2) інтерпретація викладених у творах ідей не для фреймування їх рамками якихось сучасних ідеологій чи комплексів ідей, а через відтворення практики осмислення подій чи феноменів, викладених у цих творах.

Ці два підходи можна описати так: у першому випадку дослідник свідомо і відкрито повідомляє, що автор якогось тексту не міг знати про те, частиною якого надбання у майбутньому стануть його ідеї, а в другому випадку дослідник ніби ставить себе на місце автора, «вживається» у те, що в конкретних обставинах досліджуваного історичного періоду він писав, і так розуміє «практичний» смисл викладених у тексті думок.

Як приклад першого підходу можна навести книжку американського політолога Е.Б. Портіса, яка має відверто презентистську назву, але в цьому випадку у позитивному смислі: «Реконструюючи класиків» (Portis, 1998). У першій частині цієї книги автор викладає свою методологію, згідно з якою він розбирає праці Платона, Аристотеля, Святого Августина, Святого Фоми Аквінського, Мак'явеллі, Гоббса, Локка, Руссо та Маркса за чотирма питаннями: природа людини та раціональна мотивація, мотиваційна основа соціальної солідарності, функція та організація влади, загальна теорія політичних змін і політичної стабільності конкретного мислителя (Portis, 1998, с. 9-11). На основі цього Е.Б. Портіс називає «політику» згідно з кожним цим мислителем за допомогою якогось епітету: Платон і політика краси (Portis, 1998, c. 28), Св. Августин і політика гріха (Portis, 1998, с. 62), Гоббс і політика страху (Portis, 1998, с. 114) тощо.

Безумовно, не можна відразу відкидати ці метафори як однозначно хибні, тому що вони якоюсь мірою відповідають поглядам мислителів, однак з очевидністю у цьому підході ми простежуємо елемент презентизму - приписування світоглядного сприйняття політики мислителям минулого з наших сучасних позицій.

Е.Б. Портіс відкрито обгрунтовує презентизм своєї позиції: «Під час інтерпретації праці 3 політичної думки з позицій суспільствознавства ми маємо постійно пам'ятати, що наше завдання - логічне конструювання, а не історичне пояснення» (Portis, 1998, с. 7). Biн стверджує, що його підхід - неісторичний, англійською ahistorical (Portis, 1998, с. 7). За допомогою свого підходу він актуалізує класичні праці з політичної думки, привертає до них увагу читачів, тематизує ключові для політичних теорій та ідеологій питання, а в корисності всього цього не може бути сумнівів.

Прикладом з іншої царини, яка безпосередньо не стосується політичної теорії чи теорій міжнародних відносин, але яскраво ілюструє другий вид конструктивного підходу до текстів минулого з позицій сучасності, є книга українського дослідника йоги Д. Данилова «Трансформація поняття «дг'яна» у вченні йоги», яка була видана 2020-го року. Цінність цієї праці полягає саме в застосуванні грунтовного контекстуального підходу. «Для аналізу смислу, що стоїть за словом, нам знадобиться охопити структуру мислення творців цього давнього тексту» (Данилов, 2020, с. 15).

Цінними є й інтерпретації конкретних практик з позицій досвіду, наприклад про те, до чого призводить практика дг'яни - до «досягнень», відомих під терміном «сіддга», приклад одного з яких Д. Данилов інтерпретує так: «А $\square$ ima - здатність зменшуватися до атома, що, на наш погляд, слід інтерпретувати як здатність до заглиблення й деталізації в пізнанні об'єкта, із яким практик ототожнений» (Данилов, 2020, с. 133). Окрім опертя на досвід в інтерпретації розвитку досліджуваного поняття, цінним у роботі Д. Данилова є «подолання європоцентристської установки в методології (Данилов, 2020, с. 133), що є своєрідним трендом сучасності і дозволяє йому глибше проаналізувати феномен в його історичному контексті, завдяки чому саме дослідження не можна вважати презентистським.

Тепер перейдемо до ілюстрацій витонченого застосування презентистських мотивів в інтерпретації історії. Популярний шведський історик Герман Ліндківст у своїй книзі (Lindqvist, 2014), присвяченій спільному минулому Швеції та Фінляндії, розвінчує багато різних історичних міфів, які мають потужний політичний елемент.

Назва книги «Коли Фінляндія була Швецією. Історія 700 років до того, як держава розвалилася» відверто висловлює позицію їі автора, який прожив багато років зі своїми батьками 
у Фінляндії та з теплими спогадами пише про життя шведськомовної спільноти Фінляндії. Як відомо, шведська мова є другою державною мовою Фінляндії, хоча нею розмовляє дуже невелика кількість населення країни - орієнтовно 5\% (FOS, 2018). Хоча фінська і шведська мови згідно з конституцією Фінляндії мають однаковий статус, зрозуміло, що за умов такої переважної більшості фінськомовних шведськомовна спільнота може стикатися 3 певними труднощами, про які у цій книзі Г. Ліндквіст також згадує.

Звернімо увагу не на сучасну проблематику внутрішньо-фінського життя, а на історичні передумови їх формування. Другий розділ своєї книги Г. Ліндквіст назвав «Хрестовий похід, якого ніколи не було». У ньому автор розвінчує міф про так званий «хрестовий похід» Святого Еріка IX, короля Швеції, та Святого Генріха Упсальського на фінів, метою якого було навернення фінів 3 поганства до християнства. Також можна здогадатися, що «святими» вони стали вже після цього, хоча статус «святості» Еріка IX Римські Папи ніколи не визнавали.

На початку розділу історик викладає класичний «підручниковий» наратив історії Erikslegenden - легенди про Еріка, який вирішив цілком миролюбно запропонувати фінам «християнську віру і мир», але вони войовничо відкинули цю пропозицію, тож з ними довелося спілкуватися з позиції сили, після чого до Швеції Ерік повернувся переможцем. Доля вихідця з Англії, єпископа Упсальського (існування якого теж є дискусійним питанням серед істориків) Генріха у тогочасній Фінляндії була не дуже вдалою - він був вбитий сокирою. Ця трагічна історія згідно із фінською стародавньою версією виглядає досить побутовою: фінський селянин Лаллі повертається до себе додому і дізнається від своєї дружини Кертту, що швед забрав харчі і не заплатив за них. Це його розлютило, а фіналом конфлікту стало вбивство цього шведа Еріка.

У книзі Г. Ліндквіст наводить шведський переклад частини фінської легенди, в якій описується ця подія. 3 неї стає зрозумілим, що ситуація описувалася з позиції народу, який опирався колонізаторам, які дозволяли собі відбирати харчі у фінського народу через те, що були наділені більшою владою і мали потужніше військо. Для Фінляндії постать Генріха Святого $є$ дуже важливою: він є покровителем країни, одним із державних символів.

Г. Ліндквіст справедливо вказує на те, що навіть саме його існування як історичної постаті $€$ дуже спірним, а фінська версія подій навколо нього в Фінляндії скоріше за все не відповідає дійсності з дуже простої причини: імена головних героїв цієї історії є християнськими: Лаллі від Лаврентій, а Керрту - від Гертруда, тому вважати цих персонажів поганами, які мають непитомі для фінського етносу християнські імена, є щонайменше дивним.

Якщо з позицій сучасності деконструювати цю історію і з' ясувати, що не було ніякого Лаллі та Керрту, ніякого Генріха Упсальського, який хрестив фінів, то під загрозою опиняються: 1) підвалини фінської національно-історичної ідентичності, 2) класичний наратив про спільну шведсько-фінську історію. Зрозуміло, що той народ, який приніс іншому культуру понад вісім століть тому, мав би сприйматися не як загарбник, а радше як «цивілізатор», що приніс культуру умовно «дикому народові». У попередньому розділі своєї книги Г. Ліндквіст імпліцитно пише про важливість для фінського етносу контактів зі шведами, зокрема на основі мовних запозичень, покликаючись і на інших дослідників, за даними яких без запозичень зі шведської фінській мові бракувало би понять на позначення «складної соціальної організації» (швед. sofistikerad samhällsorganisation) і що до фінської мови зі шведської потрапили ті слова, які сама шведська запозичила зі «спільної європейської мови культури» (швед. europeiska kulturspråk). Вочевидь, 3 цього наративу логічно випливає, що шведи щодо фінів є тим народом, який несе культуру та виконує важливу цивілізаційну функцію.

Г. Ліндквіст у своїй книзі регулярно прокладає мости між минулим і сучасністю, висловлюючи власну політичну позицію. Він пише, що «серйозні мовні конфлікти розпочалися лише на початку XX ст., коли фінськомовні почали вимагати мовної монополії, а шведськомовні розпочали боротьбу за право розмовляти рідною мовою у своїй країні» (Lindqvist, 2014, с. 20). На сторінці перед цим після огляду багатьох різних запозичень у фінській мові, особливо зі шведської, і з мов інших сусідніх народів (новгородців, литовців), він підводить читача до такого висновку: «3 самих прадавніх часів Фінляндія була багатокультурною країною (швед. mångkulturellt land) із багатьма паралельними мовами. Протягом століть наявність багатьох 
різних мов узагалі не була якоюсь проблемою, бо більшість мешканців не чули ніякої іншої мови, крім своєї» (Lindqvist, 2014, с. 19). У його словах можна простежити натяк на те, що, мовляв, 3 давніх давен на території Фінляндії розмовляли багатьма мовами, а сучасний стан, коли фінськомовних - переважна більшість, ніби «не вписується» в історичну картину або навіть порушує умовну історичну справедливість.

Г. Ліндквіст застосовує навіть концепт «націоналізм» у негативному сенсі: «Мова не була якоюсь проблемою, взагалі нема ніяких свідчень про мовні конфлікти до XIX ст., до розквіту націоналізму» (Lindqvist, 2014, с. 60). Важко заперечити, що до XIX ст. про «розквіт націоналізму» говорити не доводиться. Інтерпретація подій минулого, які можна використати для критики чи виправдання сучасного стану речей, зокрема й мовної картини Фінляндії, є яскравою ілюстрацією презентизму в дії.

Висновки. Сутнісними характеристиками презентизму є намагання сформувати концепції минулого з позицій сучасності, спроби знайти витоки сучасних ідеологій у працях мислителів минулого, обгрунтування чи дискредитація політичних та ідеологічних позицій сучасності за допомогою тлумачення історичних подій. Презентизм як підхід до інтерпретації минулого з позицій сучасності, як намагання вписати історичну інтелектуальну спадщину в рамки сучасних політичних теорій або теорій міжнародних відносин вочевидь становить методологічний виклик.

Ідея про те, що сучасне суспільство відмовиться від пошуку в минулому сенсу того, що відбувається нині, особливо в контексті міжнародних відносин, також здається утопічною. Якщо конкретний автор відкрито пише про свою презентистську позицію та пропонує власне авторське чи нове прочитання подій або текстів минулого, то будь-яка «шкода» презентизму у такому випадку з очевидністю нейтралізується.

Дослідники також можуть намагатися інтерпретувати тексти та події за допомогою «вживання в роль», намагання побачити минувшину очима ії сучасників. Ці дві стратегії не шкодять коректному реконструюванню минулого, а також мінімізують ризики його політизованої інтерпретації, на яку можуть натякати презентистські наукові розвідки, в яких автори викладають свої конкуруючі бачення «історичної справедливості» або обгрунтовують власну критику стратегій міжнародної політики з використанням аргументів столітньої давнини.

\section{Лiтература}

Атнашев Т., Велижев А. (2018). Кембриджская школа: история и метод. Кембриджская школа: теория и практика интеллектуальной истории / Сост. Т. Атнашев, М. Велижев. М. : Новое литературное обозрение. С. 7-52.

Данилов Д. (2020). Трансформація поняття «дг'яна» у вченні йоги. К. : Дух і Літера, с. 192.

Савельева И.М., Полетаев А.В. (2005) О пользе и вреде презентизма в историографии. «Цепь времен»: Проблемы исторического сознания. М. : ИВИ РАН. С. 63-88.

Скиннер К. (2018 [1988]). Значение и понимание в истории идей. Кембриджская школа: теория и практика интеллектуальной истории / Сост. Т. Атнашев, М. Велижев. М. : Новое литературное обозрение. C. 53-122.

Finlands officiella statistik (FOS): Befolkningsstruktur [e-publikation]., Tabellbilaga Befolkningen efter språk 1980-2018. Helsinki : Statistikcentralen: http://www.stat.fi/til/vaerak/2018/vaerak_2018_2019-03-29_ tau_001_sv.html.

King P. (1995). Historical contextualism: The new historicism? History Of European Ideas, 21(2), p. 209-233. DOI: 10.1016/0191-6599(94)00248-e.

Levine L. (1996). The opening of the American mind. Beacon Press. Canons, Culture and History. Boston MA : Beacon Press.

Lindqvist H. (2014). När Finland var Sverige. Historien om dem 700 åren inna riket sprängdes. Bonnier. C. 494. Portis E. (1998). Reconstructing the classics. Chatham House. C. 208.

Schmidt B. (2013). On the history and Historiography of International Relations. In Carlsnaes, W. Carlsnaes, W. Risse-Kappen, T. \& Simmons, B. Handbook of international relations. SAGE Publications. C. 3-28.

Schmidt B.C. (1994). The historiography of academic international relations. Review of International Studies, 20(04). P. 349-367. doi:10.1017/s0260210500118169.

Thorup M. (2019). Politisk idéhistorie: Fire tilgange. Politik, 21(3). DOI: 10.7146/politik.v21i3.113008. 


\section{References}

Atnashev T., Velizhev A. (2018). Kembridzhskaya shkola: istoriya i metod [The Cambridge School: History and Method]. Kembridzhskaya shkola: teoriya i praktika intellektualnoy istorii [The Cambridge School: Theory and Practice of Intellectual History] / Sost. T. Atnashev. M. Velizhev. M. : Novoye literaturnoye obozreniye, 7-52 [in Russian].

Danylov D. (2020). Transformatsiia poniattia "dhyana" u vchenni yogy [Transformation of the concept of "dhyana" in the the teachings of yoga]. Kyiv : Dukh i Litera [in Ukrainian].

Savelyeva I.M., Poletayev A.V. (2005) O polze i vrede prezentizma v istoriografii [On the useful and the harmful of presentism in historiography]. "Tsep vremen": Problemy istoricheskogo soznaniya. M. : IVI RAN, s. 63-88 [in Russian].

Skinner K. (2018 [1969]). Znacheniye i ponimaniye $v$ istorii idey [Meaning and Understanding in the History of Ideas]. Kembridzhskaya shkola: teoriya i praktika intellektualnoy istorii [The Cambridge School: Theory and Practice of Intellectual History] / Sost. T. Atnashev. M. Velizhev. M. : Novoye literaturnoye obozreniye, 53-122 [in Russian].

Finlands officiella statistik (FOS): Befolkningsstruktur [e-publikation]. [Official statistics of Finland, Societal Structure], Tabellbilaga Befolkningen efter språk 1980-2018. Helsinki : Statistikcentralen: http:/ / www.stat.fi/ til/vaerak/2018/vaerak_2018_2019-03-29_tau_001_sv.html [in Swedish].

King P. (1995). Historical contextualism: The new historicism? History Of European Ideas, 21(2), $209-233$. DOI: 10.1016/0191-6599(94)00248-e.

Levine L. (1996). The opening of the American mind. Beacon Press. Canons, Culture and History. Boston MA : Beacon Press.

Lindqvist H. (2014). När Finland var Sverige. Historien om dem 700 åren inna riket sprängdes [When Finland was Sweden. History of 700 before the collapse of the state]. Bonnier. C. 494 [in Swedish].

Portis E. (1998). Reconstructing the classics. Chatham House. C. 208.

Schmidt B. (2013). On the history and Historiography of International Relations. In Carlsnaes, W. Carlsnaes, W. Risse-Kappen, T. \& Simmons, B. Handbook of international relations. SAGE Publications. C. 3-28.

Schmidt B.C. (1994). The historiography of academic international relations. Review of International Studies, 20(04). P. 349-367. doi:10.1017/s0260210500118169.

Thorup M. (2019). Politisk idéhistorie: Fire tilgange. [History of Political Ideas: Four Approaches] Politik, 21(3). DOI: 10.7146/politik.v21i3.113008 [in Danish].

\section{Анотація}

ЯковлєВ М. В. Минуле як відображення концепцій сучасності в міжнародних відносинах: обмеження та можливості презентизму. - Стаття.

Тлумачення історії з погляду сучасності, іiї інтерпретація 3 метою обгрунтування сучасних ідеологічних позицій, відома під назвою «презентимз», є деструктивним явищем, оскільки викривлює розуміння минулого та навіть подає хибні факти про події, яких насправді ніколи не було. Як доводиться у цій статті, абсолютно нейтральна в ідеологічному плані історіографія подій, особливо тих, які стосуються міжнародних відносин, є утопічним і недосяжним на практиці ідеалом.

Реконструювання історії для легітимації чи критики ідеологічних позицій сучасного світопорядку є всюдисутнім явищем, яке в цій статі ілюструється на прикладі шведсько-фінських відносин. Оскільки презентизм викривлює розуміння минулого, але є певною мірою неминучим, у статті пропонуються дві стратегії його застосування, які мінімізують його побічні негативні аспекти. Першою 3 них є цілеспрямована і відкрита презентистська позиція сучасних дослідників, з яких вони реінтерпретують твори чи події минулого в межах своєї методологічної рамки для відстеження в них тих ідеологем, які пізніше призвели до появи відповідних ідеологій чи парадигм. Ця позиція також відома як нове прочитання тексту / події.

Другою є реінтерпретація подій чи текстів крізь практику їхнього переосмислення з позицій їх актора чи автора, своєрідне «вживання» в роль і тогочасний контекст, намагання зрозуміти, як саме мислила та реагувала в минулому людина на те, що про вона писала і що саме сформувало ії ставлення до описаних нею подій. У статті вказується на те, що друга позиція суголосна методологічній вимозі Кембриджської школи інтелектуальної історії.

Перспективними для подальших досліджень є пошук та аналіз презентистських позицій в інтерпретації сучасної ролі України на міжнародній арені та ії місця в системі міжнародних відносин.

Ключові слова: концептологія, міждисциплінарні лінгвістично-політологічні дослідження, політична теорія, теорії міжнародних відносин, скандинавістика. 


\section{Summary}

Yakovliev M. V. The past as a reflection of the concepts of the present in international relations: limitations and possibilities of presentism. - Article.

Explication of history from the point of view of the present, its interpretation in order aimed at presenting an argument for one's modern ideological positions is known as "presentism". On the one hand it is a destructive phenomenon because it distorts an understanding of the past and even provides the broader audience with false facts about events that never actually took place.

However, on the other hand, as it is argued in this article, an ideologically neutral historiography of events, especially those related to international relations, is practically an utopian and unattainable ideal. Reconstructing history to legitimize or critique the ideological positions of the modern world order is a ubiquitous phenomenon, illustrated in this article by the example of Swedish-Finnish relations. Since presentism distorts the understanding of the past and also is inevitable, this article discusses two strategies for its application that can minimise its negative side effects. The first is the purposeful and open presentist position of a researcher who reinterprets the works or events of the past within his or her methodological framework to track those ideological components that led to the emergence of relevant ideologies or paradigms later.

This position is also known as a new reading of the text. The second is the reinterpretation of events or texts through the practice of rethinking them from the standpoint of their actor or author, a kind of "living through" the role and context of the time, trying to understand how people thought and reacted in the past to what others wrote and why. This article points out that the second position agrees with the methodological requirement of the Cambridge School of Intellectual History.

Promising for further research is the search and analysis of presentist positions in the interpretation of the modern role of Ukraine on the international arena and its place in the system of international relations.

Key words: concepts' studies, interdisciplinary linguistic-political studies, political theory, theories of international relations, Scandinavian studies. 